\title{
Disposable bioreactors: the current state-of-the-art and recommended applications in biotechnology
}

\author{
Regine Eibl • Stephan Kaiser • Renate Lombriser • \\ Dieter Eibl
}

Received: 14 December 2009/Revised: 20 December 2009/Accepted: 20 December 2009/Published online: 22 January 2010

(C) Springer-Verlag 2010

\begin{abstract}
Disposable bioreactors have increasingly been incorporated into preclinical, clinical, and production-scale biotechnological facilities over the last few years. Driven by market needs, and, in particular, by the developers and manufacturers of drugs, vaccines, and further biologicals, there has been a trend toward the use of disposable seed bioreactors as well as production bioreactors. Numerous studies documenting their advantages in use have contributed to further new developments and have resulted in the availability of a multitude of disposable bioreactor types which differ in power input, design, instrumentation, and scale of the cultivation container. In this review, the term "disposable bioreactor" is defined, the benefits and constraints of disposable bioreactors are discussed, and critical phases and milestones in the development of disposable bioreactors are summarized. An overview of the disposable bioreactors that are currently commercially available is provided, and the domination of wave-mixed, orbitally shaken, and, in particular, stirred disposable bioreactors in animal cell-derived productions at cubic meter scale is reported. The growth of this type of reactor system is attributed to the recent availability of stirred disposable benchtop systems such as the Mobius CellReady $3 \mathrm{~L}$ Bioreactor. Analysis of the data from computational fluid dynamic simulation studies and first cultivation runs confirms that this novel bioreactor system is a viable alternative to traditional cell culture bioreactors at benchtop scale.
\end{abstract}

R. Eibl $(\bowtie) \cdot$ S. Kaiser $\cdot$ R. Lombriser $\cdot$ D. Eibl School of Life Sciences and Facility Management, Institute of Biotechnology, Zurich University of Applied Sciences, P.O. Box, CH-8820 Wädenswil, Switzerland

e-mail: regine.eibl@zhaw.ch
Keywords Biomanufacturing · Bioreactor types · Cell cultures · CFD - Disposable bioreactor - Microorganisms . Mobius CellReady 3 L bioreactor

\section{Introduction}

According to Chmiel (2006), a bioreactor is a closed system in which the production organism expresses the product of interest while controlled process conditions are guaranteed. In the case of a disposable bioreactor, the cultivation container is typically made from a plastic approved by the Food and Drug Administration (e.g., polyethylene, polystyrene, polytetrafluorethylene, polypropylene (PP), or ethylene vinyl acetate; Eibl and Eibl 2006) and not glass or stainless steel, as was the case in traditional designs. In its simplest configuration, the disposable bioreactor consists of just a non-instrumented cultivation container and hence requires an external device (e.g., $\mathrm{CO}_{2}$ incubator, shaker) to provide the optimal environment for cell growth and/or product formation. Such a system is suitable primarily for small volume cultivations at milliliter scale. Disposable bioreactors operating with culture volumes of $1 \mathrm{~L}$ or more are used preferably with their own unit for measurement and control of relevant process parameters. This means that they are equipped with disposable and/or standard online sensors allowing, for example, monitoring of temperature, $\mathrm{pH}$, and dissolved oxygen (DO).

The advantages of disposable bioreactors such as high flexibility, easy handling, reduced incidence of crosscontamination, and savings in time and costs (Lim and Sinclair 2007; Foulon et al. 2008; Behme 2009; Mauter 2009) are ascribed to the pre-sterility of the cultivation container which is guaranteed by the vendor. Critical issues 
currently restricting the use of disposable bioreactors arise from the limited experience of using such bioreactors, insufficient plastic material strength, in addition to scalability and the single-use philosophy itself (Eibl and Eibl 2008a). Renewal of the disposable cultivation container also contributes to an increase in the costs of solid waste disposal and consumables, resulting in higher running costs, thereby limiting the adoption of advanced automated solutions. In addition, the commercial availability of reliable, disposable sensors (Rao et al. 2009) for the measurement and control of the main process parameters and peripheral elements, such as valves, sampling systems, and couplers, is restricted. A further limiting factor is the time required to train staff in order to ensure trouble-free operation of disposable bioreactors, which may increase as disposable bioreactors of larger culture volume are used. However, the most controversial issue has been the detection of extractables and leachables (van Tienhoven et al. 2006; Altaras et al. 2007; Jenke 2007; Okonkowski et al. 2007) which can interact with the product.

Notwithstanding the constraints mentioned above, disposable bioreactors possessing either a rigid (tube, plate, flask, cylindrical vessel) or a flexible (bag) cultivation container have gained importance as will be discussed in the summary of their development. An assessment of the disposable bioreactors currently available including their power input, type, scale, as well as application confirms the current popularity of mechanically driven and, in particular, stirred disposable bioreactor systems. The Mobius CellReady $3 \mathrm{~L}$ bioreactor is a recently introduced example of such a bioreactor system which was used for Chinese hamster ovary $(\mathrm{CHO})$ cell cultivations and computational fluid dynamic (CFD) simulations, the results of which are both presented for the first time in this paper. Finally, current trends in the selection of disposable bioreactors are summarized.

\section{Development phases and milestones}

Phase 1

The development of disposable bioreactors can be described in three phases. Phase 1 covering the early beginnings dates back nearly 50 years. At this time, glass Petri dishes had already been replaced by their plastic counterparts in many microbial laboratories. In 1963, Falch and Heden (Falch and Heden 1963) at the Karolinska Institute in Stockholm reported the successful application of shaken tetrahedron bags made of PP and Teflon which had been made in their own laboratory. Interestingly, they observed excellent growth for Bacillus subtilis, Escherichia coli, and Serratia marcescens cells.
Phase 2

Approximately 10 years later, development phase 2 saw the introduction of hollow fiber technology by Knazek and his team (Knazek et al. 1972). The resulting hydraulically driven hollow fiber bioreactor systems were favored for continuous in vitro production of hybridoma-derived monoclonal antibodies (mAbs) at low volume scale (100 mg to several grams) in the $1980 \mathrm{~s}$ and $1990 \mathrm{~s}$ (Hopkinson 1985; Gorter et al. 1993; Marx 1998; Davis 2007a). Also in phase 2, multi-tray cell culture systems such as the Cell Factory and the CellCube (Beeksma and Kompier 1995; Schwander and Rasmusen 2005) and twocompartment dialysis membrane bioreactors such as the CELLine and the MiniPerm (Falkenberg 1998; Trebak et al. 1999; Bruce et al. 2002; McArdle 2004) were introduced into animal cell culture labs. Whereas Cell Factories replaced plastic roller bottles and proved to be suitable for the commercial GMP manufacture of a few vaccines and therapeutic proteins (Hagen et al. 1996; Aunins et al. 1997; Davis 2007b; Ball et al. 2009), two-compartment dialysis bioreactors became recognized as appropriate for long-term cell expansions, screening experiments, and sample production at milliliter scale (Nagel et al. 1999; Docagne et al. 2001; Scott et al. 2001; Eibl and Eibl 2007; Adam et al. 2008). Toward the end of phase 2 , the suitability of pneumatically driven plastic bag bioreactors (bubble column type) with minimal instrumentation (Life Reactor, Ebb-and-Flow Bioreactor, Plastic-lined Bioreactor) for plant cell-derived secondary metabolite expressions was demonstrated (Ziv et al. 1998; Curtis 1999, 2004; Hsiao et al. 1999; Ziv 1999, Ziv 2000, 2005).

\section{Phase 3}

The launch of the first wave-mixed bag bioreactor system in the late 1990s marked the start of, and influenced the course of, development phase 3 , which led to the disposable bioreactor types listed in Table 1. The disposable bioreactors are differentiated based on the type of power input and encompass mechanically driven/wave-mixed, mechanically driven/stirred, mechanically driven/orbitally shaken, mechanically driven/vertically oscillating, pneumatically driven, and hybrid systems.

Mixing within the multilayer bags of the wave-mixed bioreactors listed in Table 1 is achieved through a waveinduced mixing process, resulting from the oscillating movement of a platform or of platform sections. Due to the wave movement, oxygen is incorporated in the fluid from the headspace within the bag without the formation of bubbles. The seven, wave-mixed, bag bioreactor systems are distinguished by their control mechanism, their bag design, the installed sensor types, the type of platform 
Table 1 Summary of main disposable bioreactors coming onto the market in phase 3

\begin{tabular}{|c|c|c|c|}
\hline Bioreactor brand & Vendor & Maximum size & Main applications \\
\hline \multicolumn{4}{|c|}{ Mechanically driven/wave-mixed (horizontally oscillating) } \\
\hline $\begin{array}{l}\text { BIOSTAT CultiBag RM } \\
\text { (in the past BioWave) }\end{array}$ & Sartorius Stedim & $300 \mathrm{~L} \mathrm{CV}$ & $\begin{array}{l}\text { Cultivation of animal cells, plant cells and microorganisms having } \\
\text { up to medium oxygen demands: screening, seed inoculum } \\
\text { production, small and medium volume scale manufacture }\end{array}$ \\
\hline Wave Bioreactor & GE Healthcare & $500 \mathrm{~L} \mathrm{CV}$ & \\
\hline AppliFlex & Applikon & $25 \mathrm{~L} \mathrm{CV}$ & \\
\hline Tsunami Bioreactor & TsunamiBio & $\begin{array}{l}160 \mathrm{~L} \mathrm{CV} \text { per } \\
\text { platform }\end{array}$ & \\
\hline CELL-tainer Bioreactor, animal & Lonza & $15 \mathrm{~L} \mathrm{CV}$ & $\begin{array}{l}\text { Cultivation of animal cells and plant cells: screening, } \\
\text { seed inoculum production, sample production, } \\
\text { small volume scale manufacture }\end{array}$ \\
\hline $\begin{array}{l}\text { CELL-tainer Bioreactor, } \\
\text { microbial }\end{array}$ & & & $\begin{array}{l}\text { Cultivation of microorganisms: screening, seed inoculum } \\
\text { production, sample production, small volume scale manufacture }\end{array}$ \\
\hline WUB & Nestlé & $100 \mathrm{~L} \mathrm{CV}$ & $\begin{array}{l}\text { Cultivation of plant cells: small and medium volume } \\
\text { scale manufacture }\end{array}$ \\
\hline \multicolumn{4}{|c|}{ Mechanically driven/vertically oscillating } \\
\hline BayShake Bioreactor & $\begin{array}{l}\text { Bayer Technology } \\
\text { Services/Sartorius } \\
\text { Stedim }\end{array}$ & $1,000 \mathrm{~L} \mathrm{TV}$ & $\begin{array}{l}\text { Cultivation of animal cells: seed inoculum production, sample } \\
\text { production, small and medium volume scale manufacture }\end{array}$ \\
\hline \multicolumn{4}{|c|}{ Mechanically driven/orbitally shaken } \\
\hline$\mu 24$ Microbioreactor & Applikon & $7 \mathrm{~mL} \mathrm{TV}$ & $\begin{array}{l}\text { Cultivation of animal cells, plant cells and microorganisms: } \\
\text { screening }\end{array}$ \\
\hline BioLector & mp2-labs & $1.5 \mathrm{~mL} \mathrm{TV}$ & \\
\hline CultiFlask $50 \mathrm{DB}^{\mathrm{a}}$ & Sartorius Stedim & $35 \mathrm{~mL} \mathrm{CV}$ & \\
\hline Sensolux & & $1 \mathrm{~L} \mathrm{TV}$ & \\
\hline $\begin{array}{l}\text { SB-200X Disposable Shaken } \\
\text { Bioreactor System }\end{array}$ & $\begin{array}{l}\text { Kühner/Sartorius } \\
\text { Stedim }\end{array}$ & $200 \mathrm{~L} \mathrm{TV}$ & $\begin{array}{l}\text { Cultivation of animal cells: seed inoculum production, } \\
\text { sample production, small and medium volume scale manufacture }\end{array}$ \\
\hline CURRENT Bioreactor & AmProtein & $300 \mathrm{~L} \mathrm{CV}$ & \\
\hline \multicolumn{4}{|l|}{ Mechanically driven/stirred } \\
\hline S.U.B. & ThermoFisher Scientific & $1,000 \mathrm{~L} \mathrm{CV}$ & $\begin{array}{l}\text { Cultivation of animal cells: seed inoculum production, } \\
\text { small and medium volume scale manufacture }\end{array}$ \\
\hline BIOSTAT CultiBag STR & Sartorius Stedim & $1,000 \mathrm{~L} \mathrm{CV}$ & \\
\hline Nucleo Bioreactor & ATMI Life Science & $1,000 \mathrm{~L} \mathrm{CV}$ & \\
\hline XDR-DSTB, animal & Xcellerex & $2,000 \mathrm{~L} \mathrm{CV}$ & \\
\hline XDR-DSTB, microbial & & 200 L TV & Manufacture of microbial HCD products \\
\hline Mobius CellReady 3 L Bioreactor & Applikon/Millipore & $3 \mathrm{~L} \mathrm{TV}$ & $\begin{array}{l}\text { Cultivation of animal cells: screening, seed inoculum } \\
\text { production, sample production }\end{array}$ \\
\hline CelliGen BLU SUB & New Brunswick & $14 \mathrm{~L} \mathrm{TV}$ & \\
\hline SuperSpinner D1000 & Sartorius Stedim & $1 \mathrm{~L} \mathrm{CV}$ & \\
\hline \multicolumn{4}{|l|}{ Pneumatically driven } \\
\hline SBB & Nestlé & $100 \mathrm{~L} \mathrm{CV}$ & $\begin{array}{l}\text { Cultivation of plant cells: small and medium volume scale } \\
\text { manufacture }\end{array}$ \\
\hline PBS & PBS & $250 \mathrm{~L} \mathrm{TV}$ & $\begin{array}{l}\text { Cultivation of animal cells: seed inoculum production, sample } \\
\text { production, small- and medium-volume-scale manufacture }\end{array}$ \\
\hline $\begin{array}{l}\text { CellMaker Regular } \\
\text { (in the past CellMaker Lite) }\end{array}$ & Cellexus & $50 \mathrm{~L} \mathrm{CV}$ & $\begin{array}{l}\text { Cultivation of microorganisms: seed inoculum production, } \\
\text { sample production, small-volume-scale manufacture }\end{array}$ \\
\hline \multicolumn{4}{|l|}{ Hybrid } \\
\hline CellMaker Plus & Cellexus & $8 \mathrm{~L} \mathrm{CV}$ & $\begin{array}{l}\text { Cultivation of animal cells: seed inoculum production, } \\
\text { sample production }\end{array}$ \\
\hline
\end{tabular}

$C V$ culture volume, $D B$ disposable bioreactor, $D S T B$ disposable stirred tank bioreactor, $H C D$ high cell density, $P B S$ Pneumatic Bioreactor System, $S B B$ Slug Bubble Bioreactor, $S U B$ Single-Use Bioreactor, $T V$ total volume, $W U B$ Wave and Undertow Bioreactor

${ }^{\text {a }}$ Non-instrumented 
movement, and the number of platforms. However, cell growth and product expression are always controlled via mass and energy transfer which can be adjusted, with the exception of the WUB and CELL-tainer, by modifying the rocking rate, rocking angle, filling level, and aeration rate of the moving bag. In the case of the WUB, mixing and aeration occur through periodic upward and undertow movement of movable sections of a horizontal platform (table) on which the bag is located. The parameters influencing mass and energy transfer in a WUB bag are the angle of the platform, the proportion of the culture volume located on, and lifted by, the platform, the aeration rate, and the time taken for the platform to complete one oscillation (Girard et al. 2006; Terrier et al. 2007). In contrast, the platform movement of a CELL-tainer Bioreactor is two-dimensional, which is accomplished by additional horizontal displacement, resulting in volumetric oxygen transfer rates 10 to 60 times higher than in other wave-mixed systems (Lonza 2008). In fact, CELL-tainer Bioreactor's microbial version provides the highest volumetric oxygen transfer rates (above 200 per hour) reported to date for wave-mixed systems (Lonza 2008). Thus, the microbial version of the CELL-tainer Bioreactor is preferred for limitation-free, high cell density cultivations of microorganisms having high oxygen demands.

Wave-mixed bag bioreactors are well suited to smalland medium-scale processes where cells with low to medium oxygen demands are cultivated in batch, feeding, and perfusion modes. In addition to seed inoculum, biologically active cells (Hami et al. 2003, 2004), mAbs as well as other therapeutic glycoproteins (Singh 1999; Oashi et al. 2001; Weber et al. 2002; Eibl et al. 2003a,b; Pierce and Shabram 2004; Fries et al. 2005) and viruses for vaccines and gene therapies (Genzel et al. 2004, 2006; Rios 2006; Slivac et al. 2006; Hundt et al. 2007; Negrete and Kotin 2007) can be generated by growing mammalian or insect cells in suspension or on microcarriers. Moreover, plant cell-derived secondary metabolites (Eibl and Eibl 2002; Palazón et al. 2003; Bentebibel et al. 2005), microbial niche products such as an immunomodulator (Eibl et al. 2003b), chiral building blocks (Jablonski-Lorin et al. 2003), or a Listeria monocytogenes human papillomavirus vaccine (Hitchcock 2009), biological insecticides (Canales et al. 2001; Hess et al. 2002), and masspropagated insecticidal nematodes (Hirschy et al. 2001) can be successfully produced in wave-mixed bioreactors. Recent investigations have even confirmed their suitability for the cultivation of non-Newtonian culture broths as in the case of fast growing tobacco (BY-2) cells, which have become popular for plantibody production (Ducos et al. 2008; Eibl et al. 2009a,b).

The BayShake Bioreactor, which has recently been introduced, achieves gentle mixing and surface aeration through oscillation, just as in the case of the wave-mixed bag bioreactors. However, the culture broth in this bioreactor, designed to produce animal cell-derived products, oscillates vertically in a cube-shaped bag (Kauling et al. 2007). The BayShake Bioreactor, the three pneumatically driven bag bioreactor versions, the SBB (Ducos et al. 2008; Eibl et al. 2009a), the PBS (B. Lee, PBS, October 2009, personal communication) and the CellMaker Regular (Peacock and Auton 2008), as well as the hybrid CellMaker Plus (in which the pneumatic and mechanical power input are combined; Taylor 2007) are less common than the orbitally shaken and stirred disposable systems described below.

The discovery that animal cells, just like plant cells and microorganisms, can be grown without damage due to shear stress and without oxygen limitation in noninstrumented, shaking, multiwell plates, and "Erlenmeyer" flasks resulted in the widespread application of these systems for high-throughput screening experiments at milliliter scale. In addition, the publishing of key engineering parameters (Büchs et al. 2000; Maier et al. 2003; Zhang et al. 2005; Peter et al. 2006) and the availability of the first disposable sensors enabled the development of fully characterized, stand-alone systems such as the $\mu 24$ Microbioreactor, the BioLector, and the Sensolux. A further important contribution to the application of orbitally shaken, disposable bioreactors in mammalian cell-derived processes was the invention of the TubeSpin cultivation vessel (trade name CultiFlask 50 disposable Bioreactor, distribution by Sartorius Stedim), which is a non-instrumented $50-\mathrm{mL}$ centrifuge tube with a conical bottom and a ventilated cap. Despite its simple design, this system delivers cell densities and product titers comparable to highly instrumented, reusable stirred bioreactors and wave-mixed bioreactors when used for animal suspension cell cultivations (De Jesus et al. 2004; Muller et al. 2004; Ries et al. 2009). Investigations of oxygen transfer confirmed the feasibility of using orbital shaker technology for the cultivation of mammalian cells at scales up to 1,000 L culture volume (Jia et al. 2008; Potera 2009, Zhang et al. 2009), which enabled the development of the SB200-X Disposable Shaken Bioreactor System (Anderlei et al. 2009) and the CURRENT Bioreactor product line from AmProtein.

Stirred disposable bioreactors are to date the most commonly used disposable bioreactors, although the first models only came onto the market in 2006. Since traditional stirred bioreactors represent the most commonly used, best characterized, and optimized reactor types in biotechnological production processes (Fenge and Lüllau 2006), this is not unexpected. At the time of writing, there are eight stirred disposable bioreactor types commercially available which differ in the design of their cultivation containers, being either flexible bags or rigid cylindrical vessels, and on the scale of their operation. 


\section{Stirred disposable bioreactors}

Stirred bag systems for pilot and production scale

Stirred bag systems, such as the XDR-DSTB (animal) and the S.U.B., are the stirred disposable bioreactors that have been available the longest, and consequently, they hold the market-leading position. Both systems, which are designed for animal cells, utilize cylindrical bags in which axial flow impellers and common aeration devices, such as microspargers or open-pipe spargers, gas filters, and ports for the integration of sensor probes and line sets are all preinstalled. The relevant design criteria such as container geometries and/or impeller geometries and positioning are replicated from their steel counterparts. The top-driven, sealed S.U.B. and the magnetically coupled, bottom-driven XDR-DSTB (animal) are commonly used in many seed train expansions, $\mathrm{mAb}$, and vaccine productions in which mammalian and insect cells are grown. Comparable product quality, product quantities (medium to high cell densities, protein titers in g-range), and engineering parameters to those achieved with stirred cell culture bioreactors made of stainless steel have clearly been demonstrated in numerous cultivation studies completed by such companies as Baxter, Centocor, Sanofi-Aventis, and Lonza (Ozturk 2007; Tollnik 2009; Valentine 2009). In addition, the application of the 50L S.U.B. for BY-2 cell-based antibody expression has recently been described (Eibl et al. 2009a), even though the S.U.B. design (in the case in question, with microsparger and pitched blade impeller) is not ideally suited to fastgrowing plant cells (Eibl and Eibl 2008b). It should also be mentioned that Xcellerex produced the world's first 2,000-L system which is the largest disposable bioreactor to date (Mardirosian et al. 2009). In addition, the company now offers the first version of a stirred bag bioreactor for microbial production which has successfully completed initial tests (with E. coli, Saccharomyces cerevisiae, Pseudomonas fluorescens) at Pfẽnex (Galliher 2008; P. Galliher, Xcellerex, November 2009, personal communication).

BIOSTAT CultiBag STR The top-driven BIOSTAT CultiBag STR, which can be connected to the BioPAT MFCS/Win SCADA software system, is very similar in configuration to the classic, reusable, stirred cell culture bioreactor (DeWilde et al. 2009), an observation which is supported for the 200-L system by the mixing time, volumetric oxygen transfer rate, tip speed, and specific power input data achieved, all measured at typical process conditions for animal cells. In this system, homogeneous mixing is achieved by a central stirring system consisting of two axial flow, three-blade segment impellers, or a combination of one axial flow, threeblade segment impeller, and one radial flow six-blade segment impeller. In addition, the bag can be equipped with a microsparger or sparger ring.

Nucleo Bioreactor The Nucleo Bioreactor incorporating the following special features, a cube-shaped bag, a tumbling impeller (Pad-Drive Mixing System), and dynamic sparging instead of a static structure, produced favorable results for mammalian cells in fed batch and perfusion cultivations (Castillo and Vanhamel 2007; Zambaux 2007). Product titers between $30 \%$ and $50 \%$ higher than with stirred steel bioreactors were observed in Nucleo Bioreactors running a vaccine manufacture with microcarriers. These results are due to the improved oxygen transfer and lower shear stress achieved in the Nucleo system (N. Sevé, Sanofi Aventis, October 2009, personal communication).

Stirred rigid plastic systems for laboratory scale

SuperSpinner D1000 Among stirred, rigid plastic systems, the SuperSpinner D1000, developed from Lehmann's
Fig. 1 Mobius CellReady 3 L Bioreactor. a Product picture (with kind permission of Millipore). b Velocity profile estimated with CFD. For improved clarity, all built-in components have been faded out

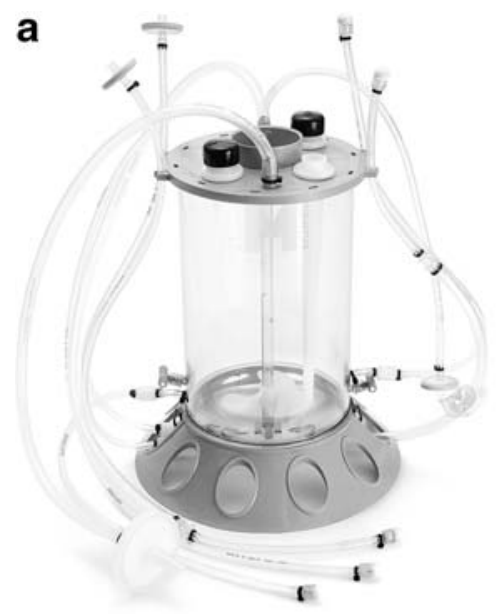

b

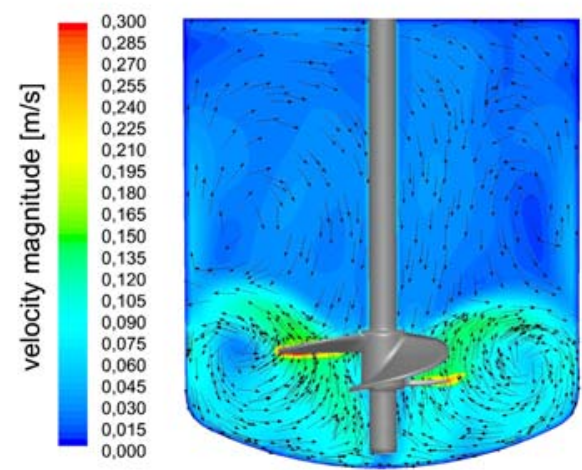


Table 2 Engineering key data of the Mobius CellReady $3 \mathrm{~L}$ Bioreactor determined for relevant cultivation conditions

\begin{tabular}{llll}
\hline Parameter & Symbol & Unit & Value \\
\hline Rotational speed & $N$ & $\mathrm{rpm}$ & $80-120$ \\
Tip speed & $u_{\text {tip }}$ & $\mathrm{m} \mathrm{s}^{-1}$ & $0.32-0.48$ \\
Specific power input & $\bar{\varepsilon}$ & $\mathrm{W} \mathrm{m}^{-3}$ & $0.83-3.06$ \\
Dissipation ratio & $\varepsilon_{\max } / \bar{\varepsilon}$ & - & $130-115$ \\
Newton number & $N e$ & - & 0.31 \\
Mixing number & $\theta_{95 \%}$ & - & 34 \\
\hline
\end{tabular}

(Lehmann et al. 1992) early glass version, has a key position. It is neither an instrumented nor a stand-alone system. SuperSpinner D1000's bubble-free aeration is achieved through the use of a hollow fiber membrane wound around a tumbling impeller. Interestingly, this active aeration provides volumetric oxygen transfer rates approximately 3.5 times greater and cell densities up to three times greater than glass standard spinners with surface aeration for animal suspension cells at $1 \mathrm{~L}$ culture volume. Based on trials completed by the authors, it can be confirmed that similar growth and metabolite courses to wave-mixed bioreactors are achievable in the SuperSpinner D1000 (Eibl et al. 2009b), thus making this system suitable for exceeding cell expansion (e.g., preclinical sample production) of animal cells.

Mobius CellReady 3 L Bioreactor The Mobius CellReady 3 L Bioreactor (Fig. 1a) is the first disposable stirred bioreactor available for use at benchtop scale with cultivations being performed in rigid plastic containers, as is the case with the SuperSpinner D1000 and the CelliGen BLU

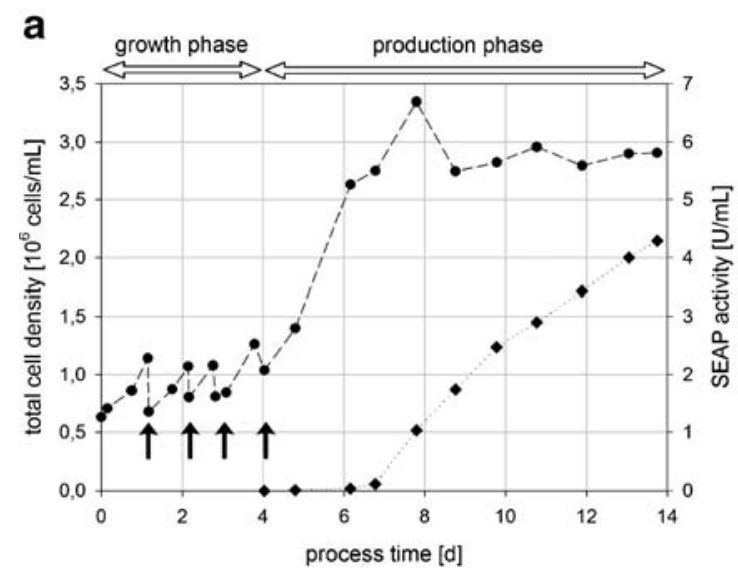

Fig. 2 Time-dependent course of growth and product formation in the case of biphasic cultivation of the SEAP expressing CHO XM 111-10 model cell line (established by the Fussenegger group, Swiss Federal Institute of Technology Zurich) in the Mobius CellReady $3 \mathrm{~L}$ Bioreactor. Growth phase was performed in feeding mode (mixture
SUB. In trials performed by the authors, vessels having a total volume of $3 \mathrm{~L}$ (2.4 L culture volume) were used, each being equipped with a three-blade marine impeller and a microsparger (Millipore 2009). Standard sensors for $\mathrm{pH}$ and sensors for DO and temperature from ez-Control (Applikon Biotechnology) were used to achieve process control. Interestingly, the dominance of the impeller's radial flow component (Fig. 1b) is readily apparent from the initial CFD simulations (the implementation of stirring movement via the moving reference frame method and description of turbulence using Launder and Spalding's standard $k-\varepsilon$ model). This flow field is, however, more typical for pitched blade impellers. Key engineering data of the Mobius CellReady Bioreactor, which have been determined for relevant cultivation conditions on the basis of the fluid flow and subsequently experimentally verified (Table 2), were comparable to those of a standard cell culture bioreactor with pitched blade impeller and sparger ring (such as the Biostat B plus 2 L operating at the authors' laboratory).

As expected, the first cultivations of $\mathrm{CHO}$ suspension cells grown in chemically defined minimal culture media (CHO Master HP-1 and HP-5, Cell Culture Technologies) provided results for cell growth and product expression comparable to those of the Biostat B plus. In the Mobius CellReady Bioreactor, doubling times of $23 \mathrm{~h}$, corresponding to a maximum growth rate of 0.03 per hour, were achieved. The maximum total cell density was $3.3 \times 10^{6}$ cells per milliliter and the secreted alkaline phosphatase (SEAP) activity was $4.9 \mathrm{U} / \mathrm{mL}$ (Fig. 2). Although further experiments are planned, it can be concluded from these results that the Mobius CellReady 3 L Bioreactor represents an alternative to standard stirred cell culture bioreactors at benchtop scale.

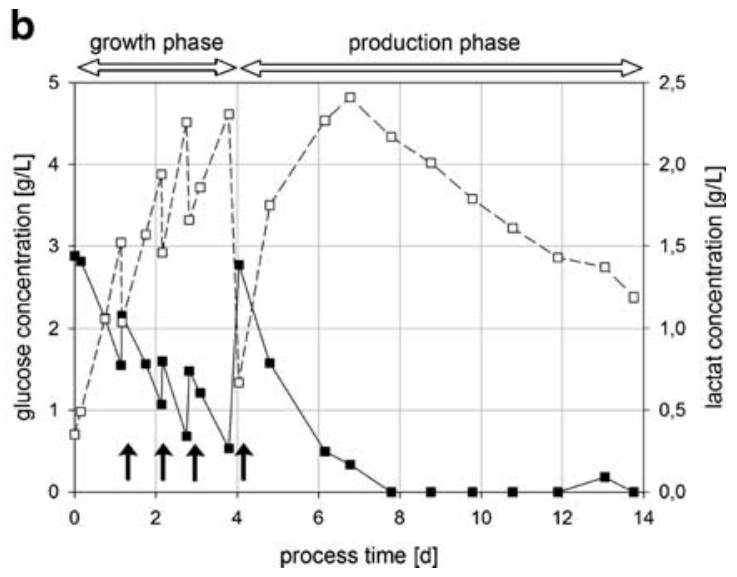

of CHO Master HP-1 and HP-5 growth medium). Production phase was induced after medium exchange (CHO Master HP-5 production medium) and temperature shift from $37^{\circ} \mathrm{C}$ to $31^{\circ} \mathrm{C}$. a Graphs of total cell density (circle) and SEAP activity (diamond). b Graphs of glucose (filled square) and lactate concentrations (empty square) 


\section{Conclusions and future trends}

The variety of disposable bioreactors currently available, encompassing wave-mixed, orbitally shaken or stirred reactors used to cultivate animal cells, and in a few cases plant cells, from milliliter to cubic meter scale, have been briefly reviewed. Microbial versions of the XDR-DSTB, the CellMaker, and the CELL-tainer Bioreactor even allow the usage of systems that have been specially designed for growing microorganisms to high cell densities. Nevertheless, there are still limitations with regard to the measurement range of the existing disposable sensors and scalability (three digit range) for plant cell and microorganism cultivations. Moreover, for plant cell and microorganism-derived productions, it should be noted that the application of disposable bioreactors only becomes cost-effective for high-value products due to the high cost of consumable material. On the other hand, scalable, less-instrumented, low-cost versions such as the WUB are in demand for low-value products.

The selection of a disposable bioreactor for animal cells is dependent on a number of factors. Naturally, the cultivation task (biomass or cell production, expression of a biologically active substance) and the production cell line, characterized by its morphology, growth, and production behavior, have a strong impact on the selection of the disposable bioreactor type. The scale of the bioreactor and its engineering parameters, including fluid flow pattern, mixing times, residence time distribution, volumetric oxygen transfer rates, specific power input data, shear stress distribution, etc., are also critical factors. For example, numeric and experimental investigations of fluid flow in wave-mixed bioreactors (Öncül et al. 2009; Eibl et al. 2009b) demonstrate that laminar flow and thus low shear stress exist when typical process parameters for animal cells are presupposed. Furthermore, simulation studies suggest that the time during which the cells are exposed to local shear stress is lower than in stirred cell culture bioreactors (Werner 2009), both of which could explain the apparent superiority of wave-mixed bag bioreactors demonstrated in certain studies with animal cells. Additional selection factors, not to be underestimated, include the legal requirements with which the bioreactor must comply (biosafety, GMP compliance), the capital and running costs and the available infrastructure. The mutual trust between customer and vendor and the know-how of staff in bioreactor operation may also play important roles. The rapid acceptance and widespread use of stirred disposable bioreactors suggest that companies with experience of stirred standard cell culture bioreactors prefer their stirred disposable counterparts. An exception is the production of inoculum where wave-mixed bioreactors still dominate. The extent to which orbitally shaken disposable bioreactors or novel versions, such as the pneumatically driven system from PBS, will be utilized at production scale depends on their cultivation results and their engineering data. The availability of the appropriate engineering data will finally allow a direct comparison with stirred systems, which provide the benchmark for the majority of biotechnological processes to date.

\section{References}

Adam E, Sarrazin S, Landolfi C, Motte V, Lortat-Jacob H, Lassalle P, Delehedde M (2008) Efficient long-term and high-yielded production of a recombinant proteoglycan in eukaryotic HEK293 cells using a membrane-based bioreactor. Biochem Biophys Res Commun 369:297-302

Altaras GM, Eklund C, Ranucci C, Maheswari G (2007) Quantitation of lipids with polymer surfaces in cell culture. Biotechnol Bioeng 96:999-1007

Anderlei T, Cesana C, De Jesus M, Kühner M, Wurm F (2009) Shaken bioreactors provide culture alternative. GEN 29. Available at: http://www.genengnews.com/issues/articleindex.aspx, accessed 5 December 2009

Aunins JB, Bibila TA, Gatchalian S, Hunt GR, Junker BH, Lewis JA, Seifert DB, Licari P, Ramasubramanyan K, Ranucci CS, Seamans TC, ZhouW WW, Buckland BC (1997) Reactor development for the hepatitis A vaccine VAQTA. In: Carrondo MJT, Griffiths B, Moreira JLP (eds) Animal cell technology: from vaccine to genetic medicine. Kluwer, Dordrecht, pp 175-183

Ball P, Crawford B, Lindström K (2009) 21st century vaccine manufacturing. BioProcess Int 4:18-28

Beeksma LA, Kompier R (1995) Cell growth and virus propagation in the costar cell cube system. In: Beuvery EC, Griffiths JB, Zeijlemaker WP (eds) Animal cell technology: developments towards the 21st century. Kluwer, Dordrecht, pp 661-663

Behme S (2009) Production facilities. In: Behme S (ed) Manufacturing of pharmaceutical proteins. Wiley VCH, Weinheim, pp 227-275

Bentebibel S, Moyano E, Palazón J, Cusidó RM, Bonfill M, Eibl R, Pinyol MT (2005) Effects of immobilization by entrapment in alginate and scale-up on paclitaxel and baccatin III production in cell suspension cultures of Taxus baccata. Biotechnol Bioeng 89:647-655

Bruce MP, Boyd V, Duch C, White JR (2002) Dialysis-based bioreactor systems for the production of monoclonal antibodies - alternatives to ascites production in mice. J Immunol Methods 264:59-68

Büchs J, Maier U, Milbradt C, Zoels B (2000) Power consumption in shaking flasks on rotary shaking machines: I. Power consumption measurements in unbaffled flask at low viscosity. Biotechnol Bioeng 68:589-593

Canales R, Hlubina M, Baier U, Tuor U (2001) Evaluation of cultivation parameters for mass production of Erynia neoaphidis. IOBC Meeting "Entomopathogens and insect parasite nematodes". Athens, Greece

Castillo J, Vanhamel S (2007) Cultivating anchorage-dependent cells. Gen 27:40-41

Chmiel H (2006) Bioreaktoren. In: Chmiel H (ed) Bioprozesstechnik. Elsevier, München, pp 195-215

Curtis WR (1999) Achieving economic feasibility for moderate-value food and flavour additives. In: Fu T, Singh G, Curtis WR (eds) Plant cell and tissue culture for the production of food ingredients. Kluwer, New York, pp 225-236

Curtis WR (2004) Growing cells in a reservoir formed of a flexible sterile plastic liner. US Patent 6,709,862B2 
Davis JM (2007a) Hollow fibre cell culture. In: Pörtner R (ed) Animal cell biotechnology: methods and protocols. Humana, Totowa, pp 337-352

Davis JM (2007b) Systems for cell culture scale-up. In: Stacey G, Davis JM (eds) Medicines from animal cell culture. Wiley, Chichester, pp 145-171

De Jesus MJ, Girard P, Bourgeois M, Baumgartner G, Kacko B, Amstutz H, Wurm FM (2004) TubeSpin satellites: a fast track approach for process development with animal cells using shaking technology. Biochem Eng J 17:217-223

DeWilde D, Noack U, Kahlert W, Barbaroux M, Greller G (2009) Bridging the gap from reusable to single-use manufacturing with stirred, single-use bioreactors. BioProcess Int 7(Suppl 4):3641

Docagne F, Colloc'h N, Bougueret V, Page M, Paput J, Tripier M, Dutartre P, MacKenzie ET, Buisson A, Komesli S, Vivien D (2001) A soluble transforming growth factor-beta (TGF-beta) type I receptor mimics TGF-beta responses. J Biol Chem 276:46243-46250

Ducos JP, Terrier B, Courtois D, Pètiard V (2008) Improvement of plastic-based disposable bioreactors for plant science needs. Phytochem Rev 7:607-613

Eibl R, Eibl D (2002) Bioreactors for plant cell and tisue cultures. In: Oksman-Caldentey KM, Barz WH (eds) Plant biotechnology and transgenic plants. Marcel Dekker, New York, pp 163-199

Eibl R, Rutschmann K, Lisica L, Eibl D (2003a) Kosten reduzieren durch Einwegbioreaktoren? BioWorld 5:22-23

Eibl R, Eibl D, Pechmann G, Ducommun C, Lisica L, Lisica S, Blum P, Schär M, Wolfram L, Rhiel M, Emmerling M, Röll M, Lettenbauer C, Rothmaier M, Flükiger M (2003b) Produktion pharmazeutischer Wirkstoffe in disposable Systemen bis zum $100 \mathrm{~L}$ Massstab, Teil 1. KTI-Projekt 5844.2 FHS, Final report, Primary data of the experiments and summary of calculations, University of Applied Sciences Wädenswil, Switzerland, unpublished

Eibl R, Eibl D (2006) Design and use of the wave bioreactor for plant cell culture. In: Gutta Dupta S, Ibaraki Y (eds) Plant tissue culture engineering. Springer, Dordrecht, pp 203-227

Eibl R, Eibl D (2007) Disposable bioreactors for inoculum production and protein expression. In: Pörtner R (ed) Animal cell biotechnology: methods and protocols. Humana, Totowa, pp 321-335

Eibl R, Eibl D (2008a) Bioreactors for mammalian cells: general overview. In: Eibl R, Eibl D, Pörtner R, Catapano G, Czermak P (eds) Cell and tissue reaction engineering. Springer, Heidelberg, pp 55-82

Eibl R, Eibl D (2008b) Design of bioreactors suitable for plant cell and tissue cultures. Phytochem Rev 7:593-598

Eibl R, Werner S, Eibl D (2009a) Disposable bioreactors for plant liquid cultures at litre-scale: review. Eng Life Sci 9:156-164

Eibl R, Werner S, Eibl D (2009b) Bag bioreactor based on waveinduced motion: characteristics and applications. In: Eibl R, Eibl D (eds) Disposable bioreactors. series adv biochem eng biotechnol 115. Springer, Heidelberg, pp 55-87

Falch FA, Heden CG (1963) Disposable shaker flasks. Biotechnol Bioeng 5:211-220

Falkenberg FW (1998) Production of monoclonal antibodies in the miniPerm bioreactor: comparison with other hybridoma culture methods. Res Immunol 6:560-570

Fenge C, Lüllau E (2006) Cell culture bioreactors. In: Ozturk SS, Hu WS (eds) Cell culture technology for pharmaceutical and cellbased therapies. CRC, New York, pp 155-224

Foulon A, Trach F, Pralong A, Proctor M, Lim J (2008) Using disposables in an antibody production process: a cost-effectiveness study of technology transfer between two production sites. BioProcess Int 6 (Suppl 3):12-18

Fries S, Glazomitsky K, Woods A, Forrest G, Hsu A, Olewinski R, Robinson D, Chartrain M (2005) Evaluation of disposable bioreactors. BioProcess Int 3(Suppl 6):36-44
Galliher P (2008) Achieving high-efficiency production with microbial technology in a single-use bioreactor platform. BioProcess Int 11:60-65

Genzel Y, Behrendt I, Koenig S, Sann H, Reichl U (2004) Metabolism of MDCK cells during cell growth and influence on virus production in large-scale microcarrier culture. Vaccine 22:22022208

Genzel Y, Olmer RM, Schaefer B, Reichl U (2006) Wave microcarrier cultivation of MDCK cells for influenza virus production in serum containing and serum-free media. Vaccine 24:6074-6087

Girard LS, Fabis MJ, Bastin M, Courtois D, Pétiard V, Koprowski H (2006) Expression of a human anti-rabies virus monoclonal antibody in tobacco cell culture. BBRC 345:602-607

Gorter A, van de Griend RJ, van Eendenburg JD, Haasnot WH, Fleuren GJ (1993) Production of bi-specific monoclonal antibodies in a hollow-fibre bioreactor. J Immunol Methods 161:145-150

Hagen AJ, Aboud RA, DePhillips PA, Oliver CN, Orella CJ, Sitrin RD (1996) Use of nuclease enzyme in the purification of VAQTA, a hepatitis A vaccine. Biotechnol Appl Biochem 23:209-215

Hami LS, Chana H, Yuan V, Craig S (2003) Comparison of a static process and a bioreactor-based process for the GMP manufacture of autologous Xcellerated T cells for clinical trials. BioProcessing J 2:1-10

Hami LS, Green C, Leshinsky N, Markham E, Miller K, Craig S (2004) GMP production of Xcellerated T cells for the treatment of patients with CLL. Cytotherapy 6:554-562

Hess S, Baier U, Lettenbauer C, Hafner D (2002) A new application for the wave bioreactor 20: cultivation of Erynia neoaphidis, a mycel producing fungus. IOBC Meeting "Insect pathogens and insect parasitic nematodes". Birmingham, UK

Hirschy O, Schmid T, Grunder JM, Andermatt M, Bollhalder F, Sievers M (2001) Wave reactor and the liquid culture of the entomopathogenic nematode Steinerma feltiae. In: Griffin CT, Burnell AM, Downes MJ, Mulder R (eds) Developments in entomopathogenic nematode/bacterial research. DG XII, COST 819, Brussels, Luxembourg

Hitchcock T (2009) Production of recombinant whole-cell vaccines with disposable manufacturing systems. BioProcess Int 5:36-45

Hopkinson J (1985) Hollow fibre cell culture systems for economical cell-product manufacturing. BioTechnol 3:225-230

Hsiao TY, Bacani FT, Carvalho EB, Curtis WR (1999) Development of a low capital investment reactor system: application for plant cell suspension culture. Biotechnol Prog 15:114-122

Hundt B, Best C, Schlawin N, Kassner H, Genzel Y, Reichl U (2007) Establishment of a mink enteritis vaccine production process in stirred-tank reactor and Wave ${ }^{\mathbb{B}}$ Bioreactor microcarrier cultures in 1-10 L scale. Vaccine 25:3987-3995

Jablonski-Lorin C, Mellio V, Hungerbühler E (2003) Stereoselective bioreduction to a chiral building block on a kilogram scale. Chimia 57:574-576

Jenke D (2007) Evaluation of the chemical compatibility of plastic contact materials and pharmaceutical products; safety considerations related to extractables and leachables. J Pharm Sci 96:2566-2581

Jia Q, Li H, Hui M, Hui N, Joudi A, Rishton G, Bao L, Shi M, Zhang X, Luanfeng L, Xu J, Leng G (2008) A bioreactor system based on a novel oxygen transfer method. BioProcess Int 6:66-78

Kauling J, Brod H, Schmidt S, Poggel M, Frahm B, Rose R (2007) Einweg-Bioreaktor. Patent DE102006018824A1

Knazek RA, Gullino PM, Kohler PO, Dedrick RL (1972) Cell culture on artificial capillaries: an approach to tissue growth in vitro. Science 178:65-67

Lehmann J, Heidemann R, Riese U, Lütkemeyer D, Büntemeyer H (1992) Der Superspinner-Ein "Brutschrankfermenter" für die Massenkultur tierischer Zellen. BioEngineering 5(6):112-117 
Lim JAC, Sinclair A (2007) Process economy of disposable manufacturing: process models to minimize upfront investment. Am Pharm Rev 10:114-121

Lonza (2008) CELL-tainer single-use bioreactors. Walkersville, Brochure

Maier U, Losen M, Büchs J (2003) Advances in understanding and modeling the gas-liquid mass transfer in shake flasks. Biochem Eng J 17:155-167

Mardirosian D, Guertin P, Crowell J, Yetz-Aldape J, Hall M, Hodge G, Jonnalagadda K, Holmgren A, Galliher P (2009) Scaling up a CHO-produced hormone-protein fusion product. BioProcess Int 7(Suppl 4):30-35

Marx U (1998) Membrane-based cell culture technologies: a scientifically economically satisfactory alternative malignant ascites production for monoclonal antibodies. Res Immunol 6:557-559

Mauter M (2009) Environmental life-cycle assessment of disposable bioreactors. BioProcess Int 7(Suppl 4):18-28

McArdle J (2004) Report of the workshop on monoclonal antibodies. ATLA 32(Suppl 1):119-122

Millipore (2009) Datasheet Mobius ${ }^{\circledR}$ CellReady 3 L Bioreactor. Available at: http://www.millipore.com/publications.nsf/ a 73664f9f9 81 af 8 c 852569 b 9005 b 4 eee/ 228 eeedd 2285 ebe1852575de00570375/\$FILE/DS26770000.pdf, accessed 1 December 2009

Muller N, Girard P, Hacker D, Jordan M, Wurm FM (2004) Orbital shaker technology for the cultivation of mammalian cells in suspension. Biotechnol Bioeng 89:400-406

Nagel A, Koch S, Valley U, Emmrich F, Marx U (1999) Membranebased cell culture systems - an alternative to in vivo production of monoclonal antibodies. Dev Biol Stand 101:57-64

Negrete A, Kotin RM (2007) Production of recombinant adenoassociated vectors using two bioreactor configurations at different scales. J Virol 145:155-161

Oashi R, Singh V, Hamel JFP (2001) Perfusion culture in disposable bioreactors. GEN 21(40):78

Okonkowski J, Balasubramanian U, Seamans C, Fischrogen Z, Zhang J, Lachs P, Robinson D, Chartrain M (2007) Cholesterol delivery to NS0 cells: challenges and solutions in disposable linear low-density polyethylene-based bioreactors. J Biosci Bioeng 103:50-59

Ozturk SS (2007) Comparison of product quality: disposable and stainless steel bioreactor. BioProduction, Berlin

Öncül AA, Kalmbach A, Genzel Y, Reichl U, Thévenin D (2009) Numerische und experimentelle Untersuchungen der Fliessbedingungen in Wave-Bioreaktoren. CIT 81:1241

Palazón J, Mallol A, Eibl R, Lettenbauer C, Cusido RM, Pinyol MT (2003) Growth and ginsenoside production in hairy root cultures of Panax ginseng using a novel bioreactor. Planta Med 69:344 349

Peacock L, Auton KA (2008) Comparing shaker flasks with a singleuse bioreactor for growing yeast seed cultures. BioProcess Int 6:54-57

Peter CP, Suzuki Y, Büchs J (2006) Hydromechanical stress in shake flask: correlation for the maximum local energy dissipation rate. Biotechnol Bioeng 93:1164-1176

Pierce LN, Shabram PW (2004) Scalability of a disposable bioreactor from $25 \mathrm{~L}-500 \mathrm{~L}$ run in perfusion mode with a $\mathrm{CHO}$ cell-based cell line: a tech review. BioProcessing J 4:51-56

Potera C (2009) Firm on quest to improve biomanufacturing. GEN 29:20-21

Rao G, Moreira A, Brorson K (2009) Disposable bioprocessing: the future has arrived. Biotechnol Bioeng 102:348-356
Ries C, John C, Eibl R (2009) Einwegbioreaktoren für die Prozessentwicklung mit Insektenzellen. BioForum 3:11-13

Rios M (2006) Process considerations for cell-based influenza vaccines. PharmaTech 4:1-6

Schwander E, Rasmusen H (2005) Scalable, controlled growth of adherent cells in a disposable, multilayer format. GEN 25:29

Scott LE, Aggett H, Glencross DK (2001) Manufacture of pure antibodies by heterogeneous culture without downstream purification. Biotechniques 31:666-668

Singh V (1999) Disposable bioreactor for cell culture using waveinduced motion. Cytotechnology 30:149-158

Slivac I, Srček VG, Radoševic K, Kmetič I, Kniewald Z (2006) Aujeszky's disease virus production in disposable bioreactors. J Biosci 3:363-368

Taylor I (2007) The CellMaker plus single-use bioreactor: a new bioreactor capable of culturing bacteria, yeast, insect and mammalian cells. Biotechnica, Hannover

Terrier B, Courtois C, Hénault N, Cuvier A, Bastin M, Aknin A, Dubreuil J, Pétiard V (2007) Two new disposable bioreactors for plant cell cultures: the wave $\&$ undertow bioreactor and the slugg bubble bioreactor. Biotechnol Bioeng 96:914-923

Tollnik C (2009) Einsatz von Disposables in der Praxis - ein Erfahrungsbericht zu Design und Betrieb einer Pilotanlage für klinische Wirkstoffproduktionen. 2. Konferenz Einsatz von SingleUse-Disposables (Concept Heidelberg), Mannheim, Germany

Trebak M, Chong JM, Herlyn D, Speicher DW (1999) Efficient laboratory-scale production of monoclonal antibodies using membrane-based high-density cell culture technology. J Immunol Methods 230:59-70

Valentine P (2009) Implementation of a single-use stirred bioreactor at pilot and GMP manufacturing scale for mammalian cell culture. ESACT 2009 Meeting, Dublin, Ireland

van Tienhoven EAE, Korbee D, Schipper L, Verharen HW, De Jong WH (2006) In vitro and in vivo (cyto) toxicity assays using PVC and LDPE as model materials. J Biomed Mater Res A78:175-182

Weber W, Weber E, Geisse S, Memmert K (2002) Optimisation of protein expression and establishment of the wave bioreactor for baculovirus/insect cell culture. Cytotechnology 38:77-85

Werner S (2009) Wave-mixed bioreactors: characterization and scaling-up by using CFD. BioProduction, Barcelona

Zambaux JP (2007) How synergy answers the biotech industry needs. BioProduction, Berlin

Zhang H, Williams-Dalson W, Keshavarz-Moore E, Shamlou P (2005) Computational-fluid-dynamics (CFD) analysis of mixing and gas-liquid mass transfer in shake flasks. Biotechnol Appl Biochem 41:1-8

Zhang X, Bürki CA, Stettler M, De Sanctis D, Perrone M, Discacciati M, Parolini N, DeJesus M, Hacker DL, Quarteroni A, Wurm FM (2009) Efficient oxygen transfer by surface aeration in shaken cylindrical containers for mammalian cell cultivation at volumetric scales up to $1000 \mathrm{~L}$. Biochem Eng J 45:41-47

Ziv M, Ronen G, Raviv M (1998) Proliferation of meristematic clusters in disposable pre-sterilized plastic biocontainers for the large-scale propagation of plants. In Vitro Cell Dev Biol-Plant 34:152-158

Ziv M (1999) In: Altmann A, Ziv M, Izhar S (eds) Organogenic plant regeneration in bioreactors. Kluwer, Dordrecht, pp 673-676

Ziv M (2000) Bioreactor technology for plant micropropagation. Hortic Rev 24:1-30

Ziv M (2005) Simple bioreactors for mass propagation of plants. Plant Cell Tissue Org Cult 81:277-285 